\title{
Studia posttotalitarne
}

\section{SZKAREATNY BEAZEN CZYLI O MIMIKRZE I STRATEGIACH DE/MASKOWANIA TOTALITARYZMU}

\author{
SYLWIA NOWAK-BAJCAR ${ }^{1}$ \\ (Uniwersytet Jagielloński, Kraków)
}

\begin{abstract}
Słowa kluczowe: błazen, mimikra, totalitaryzm, Boba Blagojević, narracja, titoizm, proza w Socjalistycznej Federacyjnej Republice Jugosławii, Naga Wyspa

Key words: clown, mimicry, totalitarianism, Boba Blagojević, narration, titoism, prose in the Socialist Federal Republic of Yugoslavia, Bare Island
\end{abstract}

\begin{abstract}
Abstrakt: Sylwia Nowak-Bajcar, SZKARŁATNY BŁAZEN CZYLI O MIMIKRZE I STRATEGIACH DE/MASKOWANIA TOTALITARYZMU. „PORÓWNANIA” 19, 2016. T. XIX. S. 114-129. ISSN 1733-165X. Figurą błazna chętnie posługiwali się twórcy modernizmu i awangardy, diagnozując sytuację artysty balansującego pomiędzy życiem i śmiercią, upadkiem i wzlotem, niebem i piekłem, pomiędzy dobrem i złem. Maska błazna jako znak przynależności twórców i sztuki do innego porządku chroniła przed konsekwencjami przekraczania tabu, ale także stawała się symboliczną egzemplifikacją tragicznej egzystencji (samotności) artysty i upadku kultury w nowoczesnym świecie (Jung 489-496, Starobinsky 308-323, Bachtin 366-375). Powieść serbskiej pisarki Boby Blagojević Skerletna luda (Szkarłatny błazen) z 1991 roku podejmująca rozważania na temat kondycji człowieka, władzy i ojczyzny oraz uwikłań sztuki i ideologii stanie się impulsem do refleksji nad stosowanymi przez jugosłowiańskich intelektualistów strategiami maskowania i demaskowania tematyki titoistycznych represji do końca lat osiemdziesiątych XX wieku.
\end{abstract}

\begin{abstract}
Sylwia Nowak-Bajcar, THE SCARLET CLOWN OR ABOUT MIMICRY AND STRATEGIES OF UN/COVERING TOTALITARIANISM. "PORÓWNANIA" 19, 2016. Vol. XIX. P. 114-129. ISSN 1733-165X. Authors of the modernism and the avant-garde willingly used the figure of the clown assessing a situation of the artist, balancing between the life and the death, the fall and the ascent, the sky and the hell, between the good and evil. The mask of the clown as the sign of the membership of authors and the art in other order, she protected from consequences of overstepping the taboo, but also became a symbolic exemplification of tragic existence (solitudes) of the artist and the decline in the culture in modern world (Jung 489-496, Starobinsky 308-
\end{abstract}

1 E-mail: s.nowak-bajcar@uj.edu.pl 
323, Bachtin 366-375). The novel Skerletna luda (Scarlet clown) from 1991 of the Serbian writer Boba Blagojević taking discussion about the human condition, the power and the homeland and entangling the art and the ideology will become a point of departure for reflecion on methods of masking and unmasking the subject of the titoist repression used by Yugoslav intellectals to the end of the eighties of the 20th century.

W 1991 roku w Serbii ukazała się powieść serbskiej pisarki Boby Blagojević Skerletna luda. Prva knjiga koja se zove i druga knjiga (Szkarłatny błazen. Księga pierwsza, nazywana księgą drugą) (Blagojević 1991). Szkarłat - kolor bestii (Ap 17, 3-4; Ap 17, 17-18; Ap 18) dosiadanej w Apokalipsie przez nierządnicę, symbolizujący rządy, które charakteryzuje okrucieństwo, żądza władzy i bałwochwalstwo - zostaje przez serbską autorkę odniesiony do czasów, w których rozgrywa się powieść, a więc do okresu komunizmu. Motto utworu - fragment Listu do Pizonów pochodzący ze Sztuki poetyckiej Horacego anonsuje poruszane w powieści zagadnienia dotyczące powołania i roli artysty oraz relacji między sztuką a rzeczywistością. Tłem wspomnianej problematyki, nieprzedstawionym w powieści jako przestrzeń, ale uwidaczniającym się jako ślad, blizna, piętno odciśnięte w biografii bohaterów, jest problem istnienia w titoistycznej Jugosławii obozów pracy. Problem systemu politycznego Socjalistycznej Federacyjnej Republiki Jugosławii (w dalszej części tekstu posługuję się skrótem SFRJ) jako opresyjnej kopii stalinizmu przepuszczony zostaje w utworze Blagojević przez pryzmat refleksji nad sytuacją intelektualistów uwiedzionych przez ideologiczne wizje.

Wydanie powieści zbiegło się z rozpadem Jugosławii, kiedy możliwe stało się dokonywanie nieskrępowanych rozliczeń z systemem titoistycznym. Upubliczniono wówczas wiele materiałów dokumentalnych dotyczących tej problematyki. Wcześniej, nawet po śmierci Tity (w 1980 roku), względy (auto)cenzuralne uniemożliwiały jej pełną artykulację w Jugosławii. W swojej powieści Boba Blagojević opisuje czasy poprzedzające rozpad SFRJ i do nich odnosić się będą zawarte w niniejszym artykule rozważania poświęcone strategiom maskowania i demaskowania titoizmu z perspektywy wewnętrznej, czyli w optyce uczestnika, a nie obserwatora zewnętrznego.

Žarka Svirčev, autorka interesującego tekstu: Is-povest stranosti ili poetičke transgresije Bobe Blagojević (Wy-powiedzieć obcość czyli poetologiczne transgresje Boby Blagojević) stwierdzając, że powieść Skerletna luda była już „w sposób mniej lub bardziej udany” komentowana „,z perspektywy interakcji z czasami, w których powstawała i pod kątem ideologiczno-politycznych doświadczeń, kształtujących ówczesną rzeczywistość" (Svirčev, źródło elektroniczne)², wychodzi poza kontekst historyczny powieściowych realiów i umieszcza wskazane przez siebie strategie transgresyj-

2 Svirčev odnosi się przede wszystkim do umieszczonej w drugim wydaniu powieści noty redaktorskiej pt. Napomene Predraga Bajčeticia, który zaklasyfikował utwór jako opowieść o „dzieciach ofiar titoizmu" i „,wychowywaniu" (Blagojević 2002: 379). 
ne (związane z kategorią płci i z zagadnieniami twórczości) w szerszym kontekście kulturowym. Choć badaczka stawia pytanie o to, co kryje się pod maską błazna, jej rozważania nie doprowadzają do odpowiedzi na nie, podobnie jak nie wyjaśniają innej ważnej kwestii: jaki jest sens i cel podejmowanych przez bohatera transgresji?

Czas akcji, określony przez autorkę $\mathrm{w}$ powieści precyzyjnie za pomocą dat, ma dla interpretacji znaczenie kluczowe. Blagojević sytuuje wydarzenia w dwóch przełomowych dla Jugosławii momentach. Pierwszy z nich wiąże się z rokiem 1948 i aresztowaniem ojca bohatera, który w swoistej autobiografii, za pomocą narracji wspomnieniowej, pisanej jeszcze za życia Tity (a więc w czasach represji, stąd paranoiczny strach ojca, strzegącego swych notatek), usiłuje rozliczyć się z okresem prześladowań zwolenników Stalina. Drugi istotny dla Jugosławii moment, zaprezentowany $\mathrm{w}$ powieści, rozgrywa się już po śmierci Tity (w tym planie czasowym usytuowana jest ustna "spowiedź" tytułowego bohatera, kierowana do tajemniczego S., o którym wiemy jedynie to, że jest pisarzem). Błaznem - główną postacią powieści - jest syn więźnia titoistycznego reżimu, skazanego po tzw. Aferze Biura Informacyjnego na Nagą Wyspę, który po powrocie z niej, po śmierci Tity, umiera, osierocając swoje przeszło trzydziestoletnie dziecko. Przed śmiercią były więzień powierza mu wspomnienia $\mathrm{z}$ okresu spędzonego w obozie pracy, by syn zredagował i opublikował albo spalił ów autobiograficzny dokument. Zamiar upublicznienia dowodów opresji otrzymuje w powieści wymiar symboliczny. Sprowadza się nie tylko do dylematu: pamiętać czy zapomnieć, który paraliżował poczynania ojca, ale także do dylematu: czy (i w jaki sposób) wybaczyć. Zastanawiając się nad postępowaniem ojca, bohater stwierdza:

Co go [ojca] powstrzymywało? Wspaniałomyślność? Dobroć? A przecież wybaczanie mi błędów, słabości, naiwnych wybryków przychodziło mu z takim trudem (choć starał się panować nad sobą, zachowywać racjonalnie, próbował pohamować gniew). On miałby wybaczyć? Słyszę jego szept: niczego nie wolno zapomnieć; musimy pamiętać, dokładnie i bez emocji. Czasem jednak wybaczał, wyczerpany strachem: cóż począć? A teraz ja mam przejąć tę przedawnioną sprawę, wielokrotnie odraczany proces, mam przeprowadzić śledztwo, dyskretnie, jak przystoi naszym czasom... aby pewnym osobom, żyjącym w spokoju i dobrobycie, ukołysanym przez zapomnienie u kazał się u piór przeszłości (podoba mi się słowo „upiór"); w porządku, jeżeli nie sam upiór, to przynajmniej cień tego upiora, by je odwiedził i zatrwożył miły młodzieniec, elokwentny współrozmówca na odpowiednim poziomie, wprowadzony w tematykę, będący w stanie wziąć udział w dyskusji o pewnych szczegółach z ich przeszłości [wyróż. - S.N.-B.] (Blagojević 1991: 108)3.

3 Autorką tłumaczeń cytowanych fragmentów, o ile nie wskazano innego nazwiska, jest Sylwia Nowak-Bajcar. 
Jednak zadanie stworzenia zapisu godnego tematyki dzieła - „dowodu doświadczenia" na podstawie notatek-wspomnień zmarłego ojca - „dokumentalnego śladu" ${ }^{4}$ przerasta tytułowego bohatera, który zwierzając się znanemu pisarzowi S., dostarcza mu materiału do utworu pt. Rađanje lude (Narodziny błazna), będącego jedną z części powieści. Przedstawione w niej zostaje najwcześniejsze, pełne dyscyplinującej przemocy ze strony ojca dzieciństwo syna więźnia obozu pracy. Jak dowiadujemy się z dzieła autorstwa S., ojciec tytułowego bohatera znalazł się na Nagiej Wyspie w efekcie donosu swojego kilkuletniego dziecka. Ojciec będący ofiarą systemu titoistycznego zostaje $\mathrm{w}$ tej narracji zaprezentowany jako kat własnego syna, który nie jest w stanie ujawnić opresyjności titoizmu, ponieważ upodabnia się do jego eksponentów. „Upiór” komunizmu, czy raczej - jak stwierdza w zacytowanym autoironicznym komentarzu sam bohater - "jego cień" staje się "szkarłatnym błaznem", błaznem komunizmu, który napiętnowany przeszłością swojego ojca i pozbawiony środków do życia w następujący sposób uzasadnia swoją niemoc (niezdolność do poświęcenia i wyrzeczeń):

Wszystko jestem w stanie znieść, czy też może prawie wszystko (wszystko, czego już doświadczyłem, ale nie wszystko, co mogę sobie wyobrazić), ale głodu nie zniosę i każda myśl o nim czyni mnie ospałym, słabym i lękliwym. Jestem gotowy na wszystko, byle nie być głodnym. [...] Nie mogę pozwolić na to, abym się czołgał, obrzmiały z głodu, nękany przywidzeniami, niczym zjawa, niezdolny nawet do tego, by błagać o pomoc. [...] Ojciec umarł i głód zapukał do mych drzwi, a gdy ojca pochowałem, głód przez nie wszedł; co teraz będzie? [...] Odkrywałem fakt, że o głodzie nie można myśleć; kiedy wydawało mi się, że to czynię, myślałem o jedzeniu, o wszelkich potrawach, jednej, drugiej, trzeciej, aż do całkowitego znużenia; będąc głodnym, nie potrafię myśleć o głodzie i głodujących. Ojciec to umiał, twierdził: „ubóstwo i głód obudziły we mnie awersję i nienawiść do sytych", tak napisał. Ja przeciwnie, odczuwałem przemożną potrzebę, by być jednym z nich, by być syty (Blagojević 1991: 80-81).

4 Oba terminy wykorzystała Ewa Domańska w pracy pt. Hermeneutyka przejścia (Wspomnienia z Rosji Jana Żarno), poświęconej transhumancji od „człowieka cywilizowanego do odczłowieczonego więźnia gułagu", jako narzędzia operacyjne dla swoich badań nad narracją wspomnieniową. Egzystencjalny ślad „stanowi dialog autora z samym sobą i jest sposobem na rekonstrukcję podmiotowości po traumatycznych przeżyciach. Wspomnienia tego typu są manifestacją «konwersji» i wskazują na reparacyjną rolę sfragmentaryzowanej i zniekształconej pamięci indywidualnej" natomiast narracyjne dowody doświadczenia "kierowane są przede wszystkim do innych (np. do potomności) i mają na celu ukazanie przeszłości taką, jaką naprawdę była." „[...] Wspomnienia o charakterze «dowodu doświadczenia» odnoszą się do przeszłości, która została już poddana procesom manipulacji i naznaczona jest wpływem różnych ideologii i dyskursów, takich jak np. historia [...]. W momencie przekładu (spisania przeżyć) następuje zerwanie z dyskursem pamięci. Od tej chwili ślad staje się publicznym świadectwem poddanym instytucjonalnym prawom archiwów i wystawiony jest na różnego rodzaju interpretacje" (Domańska 2006: 143-144). 
Syn za wszelką cenę pragnie uniknąć losu ojca, dlatego jego poczynaniami zaczyna kierować strach przed głodem (i przed dehumanizacją), którego świadectwem jest prowadzony przez niego „rejestr” potwierdzonych przypadków kanibalizmu oraz przywołany w powieści jako swoisty enumeracyjny "poemat" - spis najbardziej wykwintnych dań stanowiących „mroczny przedmiot pożądania" bohatera.

Zaprezentowana przeze mnie pobieżnie relacja ojca i syna odzwierciedla mechanizm działania systemu komunistycznego jako generatora przemocy i autodestrukcji. Ojciec - więzień obozu "reedukacyjnego", który po powrocie z titoistycznego łagru wychowuje swojego kilkuletniego syna - reprodukuje opresję, której sam doświadczył. Syn-donosiciel i ojciec-wychowawca powielają więc matrycę zachowań, w której ofiara i kat wymieniają się rolami. Historia twórczych przedsięwzięć ojca i syna staje się zarazem historią podejmowanych przez nich i zakończonych niepowodzeniem prób określenia swojej tożsamości.

W powieści, wpisującej się w nurt literackich refleksji nad postpamięcią, zaprezentowana zostaje niemożność przepracowania traumy przez spadkobierców systemu totalitarnego, którzy narrację o przodkach, o sobie i przeszłości przekazują nosicielom władzy (Hirsch). Dobitnym komentarzem tej sytuacji są słowa tytułowego bohatera:

Chociaż beztroskie odstępowanie autorstwa było irytujące, ratowało ono przed gniewem decydentów, którzy traktowali mnie jak sympatyczną ofiarę - kpią ze mnie, a ja uśmiechając się, milczę, pozwalając na to, by moje słowa przepadły bez śladu... i nie należały już do mnie (Blagojević 1991: 88-89).

Docierając do przyczyn narodzin „błazna komunizmu”, Boba Blagojević diagnozuje przyczynę zerwania ciągłości międzypokoleniowego przekazu jako konsekwencje postawy intelektualnej, która charakteryzuje pokolenie "synów" ofiar rozrachunków Tity z przeciwnikami politycznymi w efekcie odziedziczonej po „ojcach" nieprzepracowanej traumy. Diagnoza ta została sformułowana za pomoca postawionego przez tytułowego bohatera (i jednocześnie lapidarnie go portretującego) retorycznego pytania: „„...] w jaki sposób rozwiązać ten złożony problem moralny: co ma uczynić człowiek, którego łajdak zadłużył szlachetnym uczynkiem?" (Blagojević 1991: 89), z którego wyłania się nie buntownik, ale konformista opowiadający się po stronie sprawujących władzę "sytych”.

Powracając do kwestii tego, co skrywa maska błazna, przywołać należy rozpoznania Gastona Bachelarda zawarte w tekście Fenomenologia maski. Autor zauważa, że zakładanie maski może być podyktowane różnymi przesłankami. Wynikać ono może z chęci ukrywania się, chowania przed kimś (a więc ze strachu), potrzeby przeobrażania (a więc z potrzeby zmiany tożsamości, bycia kimś innym), chęci podobania się komuś, zjednania sobie kogoś, które Bachelard określa mianem „pod- 
rzędnych form chęci panowania" (Bachelard 20). Poruszone przez francuskiego badacza kwestie związane z intencjami zakładania maski nieuchronnie wiodą zatem ku problematyce władzy.

Tytułowy szkarłatny błazen w powieści Boby Blagojević funkcjonuje w przestrzeni społecznej dzięki swoim zdolnościom adaptacyjnym. Sam nawet, zezwalając na n a malowanie (a nie p o malowanie) swojej twarzy, stwierdza:

To prawda, [...] nie mam twarzy (jest to zaledwie drobiazg z długiej listy rzeczy, których mnie pozbawiono); poza tym, cały rodzaj ludzki jest tak różnorodny w swojej bezpostaciowości... Czym jest szacunek? Dlaczego [Lena] chciałaby mnie nim darzyć i żałuje, że nie potrafi? Niech pomyśli... (Blagojević 1991: 205).

Wspomniany brak twarzy, będący zapewne rezultatem innego niedoboru ułomnego dzieciństwa, w którym zabrakło zmarłej przedwcześnie matki i więzionego w gułagu ojca, sprawia, że bohater, skazany na nieustanne zmiany, które upodabniają go do otoczenia, staje się błaznem - „produktem” totalitarnego syste$\mathrm{mu}$, a jego tożsamość ulega rozpadowi. Błazen w odczytaniu Boby Blagojević jest paradoksalnie - figurą politycznej poprawności.

Powieść serbskiej autorki porusza zatem problem mimikry, będącej typem zachowania mimetycznego, w którym gest powtórzenia nosi znamiona deformacji - farsy. Zagadnienie to w ujęciu kolonialnym analizuje Homi Bhabha w tekście pt. Mimikra i ludzie. O dwuznaczności dyskursu kolonialnego, ale z powodzeniem, jak sądzę, można je odnieść także do rzeczywistości systemu totalitarnego, w którym postkolonialna relacja: kolonizator - kolonizowany zastąpiona zostaje relacją: system - ofiara ${ }^{5}$.

W kontekście podejmowanych tutaj problemów ważne są spostrzeżenia dotyczące charakteru gestu imitowania, który nie prowadzi do całkowitego unicestwienia różnicy pomiędzy kolonizatorem (ośrodkiem władzy) i kolonizowanym (ofiarą systemu). Ponieważ według Bhabhy mimikra „nie jest maską ukrywającą jakąś obecność czy tożsamość" (Bhabha 189), właśnie wspomniana różnica, a nie fakt, że pod maską kryje się jakieś prawdziwe oblicze, stanowi o niebezpieczeństwie mimikry. Różnica ta, charakter gestu naśladowania, który „powtarza a nie reprezentuje” (Bhabha 188), konstytuuje inność nadającą kulturze kolonialnej potencjał wywrotowy (Ashcroft, Griffiths, Tiffin 126). Rozpoznania te, z pewnymi zastrzeżeniami, można z powodzeniem odnieść do relacji ZSRR jako kolonizatora i Jugosławii jako skolonizowanego, którego wywrotowy potencjał (inność) wytworzony w procesie imitowania ujawnił się w 1948 roku. Z kolei w powieści Blagojević, obrazującej rze-

$5 \mathrm{~W}$ (post)kolonialnym ujęciu odmienność ta dotyczy koloru skóry: „Prawie taki sam, ale nie biały" - stwierdza Bhabha (191), który powołując się na Freuda, wskazuje na aporetyczny charakter kolonialnej inności (Freud 214 cyt. za: Bhabha 190-191). 
czywistość systemu totalitarnego, mimikrą posługuje się tytułowy bohater - błazen, który odtwarzając rytuały władzy (systemu edukacyjnego) wpojone mu przez ojca - więźnia gułagu, demaskuje mechanizmy jej funkcjonowania.

Natomiast kluczowe w problemie mimikry staje się pytanie o to, czy jest ona dla bohatera strategią przetrwania - mimikrą defensywną (dodajmy, że na poziomie głębokim adaptację motywuje lęk przed utratą życia, tutaj upostaciowiony przez głód), czy też mimikrą ofensywną (bohater zostaje uwiedziony przez władzę, o czym świadczy fakt upodobniania się błazna do osób, które darzy on uczuciem lub ku którym kieruje swe pragnienie) ${ }^{6}$. W rozprawach Rogera Caillois i Jacquesa Lacana problem mimikry rozpatrywany jest w oderwaniu od strachu (przetrwania), który ją motywuje (Callois 16-32; Lacan 99). Obaj badacze zgodnie eksponują moment uwiedzenia przez tło. Odnosząc się do ich rozpoznań, Ewa Domańska stwierdza:

Przypomnijmy, że dla Caillois i Lacana w mimikrze nie chodzi o strategię przetrwania, ale o bycie uwodzonym przez przestrzeń-tło, co prowadzi do wtopienia się w tło, do utraty podmiotowości i do jej rozpadu. Bhabha nie posuwa się jednak tak daleko, jak Caillois i Lacan, i proponuje następującą interpretację: ,jak przypomina nam Lacan, m i m i kr a jest jak kamuflaż; nie jest niwelowaniem różnicy, ale rodzajem podobieństwa, które [...] broni obecności przez częściowe, metonimiczne ujawnienie się". A zatem ważne jest dla niego nie tyle, by zredukować różnice, które odróżniają od tła, ale by wykorzystać podobieństwa i w ten sposób ochronić się przez częściowe (metonimiczne) ujawnienie. Kolonialna mimikra jest wprawdzie według Bhabhy strategią dostosowywania (adaptowania) innego, a tło (kolonialna władza) jest groźne i uwodzi zarówno skolonizowanego, jak i kolonizatora, jednak nie wspomina on o rozkładzie podmiotu i jego wtapianiu się w tło, bowiem chodzi o to, by skolonizowany był inny od kolonizatora. To właśnie wokół owej ambiwalentnej różnicy (skolonizowany jest prawie taki sam, jak kolonizator, ale nie całkiem) tworzy się dyskurs mimikry (Domańska, źródło elektroniczne).

Mimikra tytułowego bohatera powieści Blagojević motywowana jest zarówno potrzebą ataku, jak i obrony. Wydaje się jednak, że w obu przypadkach ontologia błazna, specyfika jego rozproszonej tożsamości jest rezultatem troski o przetrwanie / obawy o życie. Postać ta służy autorce do zaprezentowania koncepcji sztuki

6 Opierając się na klasyfikacji przyjętej w naukach przyrodniczych, Melchior Wańkowicz dokonuje rozróżnienia mimikry i kamuflażu: „Mimikra - jest to upodobnienie się do otoczenia przez zmiany dokonane na samym sobie. Kamuflaż - jest to staranie zachowania siebie jako takiego przez maskowanie nie odcinające od otoczenia. Kamuflaże bywają ofensywne (koń trojański) i defensywne (owad udający liść). I mimikry bywają ofensywne (pobożnie krzyżująca dłonie drapieżna modliszka) i defensywne (nieszkodliwy turkuć podjadek o straszliwym wyglądzie)" (Wańkowicz 299). 
stanowiącej degradację przemocy i władzy totalitarnej przez wyśmianie i komizm7. Choć błazen spełnia swą destrukcyjną rolę, obnażając mechanizmy działania systemu, godząc się pod wpływem strachu jedynie na rolę błazna, staje się on narzędziem w rękach władzy (oraz S.), chimerą pozornej wolności. Dobitnym komentarzem jego poczynań jest motto powieści: wspomniany na początku artykułu fragment Listu do Pizonów Horacego, będący krytyką poety szalonego, który swymi wybrykami nęka otoczenie.

Sceptyczny stosunek Blagojević do błazenady jako figury mimikry, będącej postawą intelektualną odziedziczoną po czasach totalitaryzmu, koresponduje z refleksją Ryszarda Legutki na temat sytuacji w Polsce poodwilżowej. Komentując esej Leszka Kołakowskiego, krakowski filozof zwrócił uwagę na fakt pojawienia się tej strategii w konkretnej, historycznej sytuacji, o specyfice której stanowiły ograniczone możliwości wyrażania niezgody:

Znienawidzona rola intelektualisty jako posłusznego asystenta w wielkiej stalinowskiej inżynierii społecznej zastąpiona inną, która tym razem wydawała się możliwa do wypełnienia, bezpieczna i pożyteczna, a dodatkowo dawała wielkie poczucie misji. W Polsce popaździernikowej w atmosferze znacznej liberalizacji i otwarcia na Zachód nowa rola intelektualisty nałożyła się na ogólny indywidualistyczny nastrój w kulturze, na modę awangardy $\mathrm{w}$ sztuce, na radosny stereotyp niepokornego artysty tworzącego swoje oryginalne dzieło $\mathrm{w}$ opozycji do opresywnego establishmentu i ciemnego drobnomieszczańskiego pospólstwa. Błazen był więc formułą, która powstała w odezwie na konkretną sytuację polityczną i tylko w niej znajdowała swoje uzasadnienie. Narodziła się ona nie w atmosferze intelektualnej powagi i duchowej harmonii, jaka najbardziej sprzyja uogólnieniom, ale w nastroju umysłowego bałaganu i chwilowego optymistycznego podniecenia, które ogarnęło inteligencję poststalinowską po zakończeniu epoki koszmaru. Jest swoistym wybrykiem fakt, że formuła ta tak bardzo obciążona konkretnością nie zniknęła szybko z polskiego życia, lecz długo była przywoływana i to zwykle w naj-

7 Jej przeciwieństwem jest w opinii Leszka Kołakowskiego wyrażonej w jego znanym eseju koncepcja artysty-kapłana i sztuki martyrologicznej, pełniącej funkcję parareligijną. Przeciwstawiając sobie obie koncepcje, wybitny filozof pisał: „Antagonizm między filozofią utrwalającą absolut i filozofią kwestionującą absoluty uznane wydaje się antagonizmem nieuleczalnym, jak nieuleczalne jest istnienie konserwatyzmu i radykalizmu we wszystkich dziedzinach ludzkiego życia. Jest to antagonizm kapłanów i błaznów, a w każdej niemal epoce historycznej filozofia kapłanów i filozofia błaznów są dwiema najogólniejszymi formami kultury umysłowej. Kapłan jest strażnikiem absolutu i tym, który utrzymuje kult dla ostateczności i oczywistości uznanych i zawartych w tradycji. Błazen jest tym, który wprawdzie obraca się w dobrym towarzystwie, ale nie należy do niego i mówi mu impertynencje; tym, który podaje w wątpliwość wszystko to, co uchodzi za oczywiste; nie mógłby tego uczynić, gdyby sam do dobrego towarzystwa należał - wtedy najwyżej mógłby być gorszycielem salonowym; błazen musi być na zewnątrz dobrego towarzystwa, oglądać je z boku, aby wykryć nie-oczywistość jego oczywistości i nie-ostateczność jego ostateczności; zarazem musi w dobrym towarzystwie się obracać, aby znać jego świętości i aby mieć okazję do mówienia mu impertynencji" (Kołakowski 178). 
mniej odpowiednich kontekstach. Najbardziej oczywistą jej wadą jest to, że dostarcza ona tak jednoznacznego i skodyfikowanego przepisu postępowania dla intelektualisty, że uwalnia go od wielu obowiązków, w tym również od podstawowych obowiązków rozróżniania i definiowania pojęć i rzeczy (Legutko 30-31) ${ }^{8}$.

Refleksje Legutki pozwalają zrozumieć znaczenie książki serbskiej pisarki, którego nie sposób w pełni docenić, nie uwzględniwszy specyfiki czasów, do których się ona odnosi, a które jawią się nie jako tzw. tło historyczne, ale jako konieczny punkt wyjścia dla wszelkich przedsięwzięć interpretacyjnych. Samo podjęcie przez Blagojević problematyki Nagiej Wyspy w 1991 roku nie było, jak wcześniej wspomniałam, nowością. Jednak w swojej powieści pisarka dociera do przyczyn niemożności przekroczenia w latach osiemdziesiątych, po śmierci marszałka Tito, stabuizowanych sposobów prezentowania okresu titoizmu. W tym ujęciu powieść Blagojević jawi się jako utwór traktujący o historii niemocy dojścia do głosu świadków wydarzeń ${ }^{9}$ oraz jako utwór wskazujący przyczyny tego stanu rzeczy. Figura szkarłatnego błazna służy serbskiej pisarce do zobrazowania działania mimikry jako problemu bolesnej spuścizny titoizmu.

Badacze podkreślają, że informacje na temat Afery Biura Informacyjnego i więźniów politycznych pojawiały się sporadycznie od 1948 roku (Dedijer 1969; Štrbac 1975; Kržavac, Marković 1976), nigdy też - jak podkreśla czarnogórski historyk, Radovan Radonjić, od lat siedemdziesiątych XX wieku zajmujący się naukowo tą problematyką - w Jugosławii oficjalnie nie zostały utajnione dokumenty dotyczące konfliktu Tity i Stalina (Bela knjiga o agresivnim postupcima vlada SSSR-a, Poljske, Čehoslovačke, Mađarske, Rumunije, Bugarske i Albanije prema Jugoslaviji; V. kongres KPJ: izvještaji i referati; VI. kongres KPJ/SKJ) czy politycznych konsekwencji tego

8 Interesującym kontekstem dla tej tematyki w perspektywie antropologiczno-kulturowej jest artykuł Moniki Sznajderman (124-131).

9 Niezwykle znamienny jest fakt nieistnienia w SFRJ przed 1980 rokiem literatury autobiograficznej, pamiętnikarsko-wspomnieniowej poświęconej doświadczeniom więziennym i obozowym w czasach Tity. W Chorwacji rozkwit pisarstwa tego typu nastąpił dopiero w latach dziewięćdziesiątych XX wieku, z dużym opóźnieniem w stosunku do literatury serbskiej czy słoweńskiej. Bardzo krytycznej oceny tej sytuacji (oraz kondycji chorwackich pisarzy) dokonuje Igor Mandić, twierdząc, że pojawienie się takich świadectw miało sens jedynie w czasach komunizmu (Mandić 242-244). Ze stanowiskiem tym polemizuje Renata Jambrešić Kirin w pracy Verbalno nasilje i razgradnja kolektivnih identiteta u iskazima političkih zatvorenika i ratnih zarobljenika (1945-1995), ujmująca problem z perspektywy badań nad pamięcią (Jambrešić Kirin, bez roku wydania: 55). Podobna cezura (lata dziewięćdziesiąte XX wieku) dotyczy pojawienia się w Serbii dokumentalnej autobiografistyki kobiecej o Nagiej Wyspie. O tych problemach pisała w Chorwacji Renata Jambrešić Kirin (2009: 47-67; 2010: 231-242), natomiast w odniesieniu do sytuacji w Serbii - Katarzyna Taczyńska. 
sporu (Radonjić 2014: 44-46), co - dodajmy - nie zmienia faktu, że nie były to informacje, do których łatwo było dotrzeć i o których dyskutowano.

W latach osiemdziesiątych, kiedy po śmierci jugosłowiańskiego marszałka nastąpiło upowszechnienie tematyki w oficjalnej historiografii (Banac; Bekić; Dedijer 1980; Štrbac 1989; Pleterski et al.; Petranović), pseudohistoriografii (Dedijer 1953; 1984) i publicystyce (Kržavac, Marković 1987), w większości publikacji istnienie jugosłowiańskich łagrów uzasadniane było wyższą - historyczną - koniecznością, której istotę zwięźle oddaje konstatacja Vladimira Dedijera: „jeżeli nie zorganizowalibyśmy tego obozu, Stalin w taki straszny obóz zamieniłby całą Jugosławię" (Dedijer 1984: 464). Ten sposób prezentacji problemu wyznaczył kierunek politycznej poprawności obowiązujący w SFRJ do jej rozpadu ${ }^{10}$.

Powieści tematyzujące doświadczenie Rezolucji Biura Informacyjnego pojawiły się już w 1954 roku (Ribnikar; Kranjec), ale dopiero w latach osiemdziesiątych wyraźnie wzrosła liczba tych utworów w Jugosławii. Do roku 1986 powstało ich około trzydziestu, chociaż dzieł, w których istnienie Nagiej Wyspy było tematem wiodącym, ukazało się zaledwie kilka: Nedovršeni krug Jary Ribnikar z 1954 roku, Tren 2 Antonija Isakovicia z 1982 roku, Otok gole istine Dragana Kalajdžicia z 1985 roku oraz Zemaljski ključ Dragana Lakićevicia z 1985 roku. W połowie lat osiemdziesiątych większość dzieł rejestrujących okres represji w literaturach jugosłowiańskich po 1948 roku została omówiona w publikacji pt. Preispitivanja. Informbiro i Goli otok u jugoslovenskom romanu (Rewizje. Biuro Informacyjne i Naga Wyspa w powieści jugosłowiańskiej) chorwackiego krytyka literackiego Milivoja Markovicia (1986).

Tego, że jeszcze w latach osiemdziesiątych tematyka poruszana przez Markovicia wydawała się „drażliwa”, dowodzi zastosowana przez niego strategia maskowania i demaskowania prawdy o titoizmie, stanowiąca dobry przykład wykorzystania mimikry, która, zgodnie z ustaleniami Bhabhy, jest „formą dyskursu kolonialnego wypowiadaną na pograniczu: pomiędzy tym, co znane i dozwolone, a tym, co chociaż znane, trzeba ukrywać: formą dyskursu wypowiadaną pomiędzy wierszami i dzięki temu zarówno łamiącą, jak i przestrzegającą zasady" (Bhabha 191).

Marković, posługując się oficjalnymi pracami historiograficznymi, fakt utworzenia obozów pracy (i zniewalania) postrzega - paradoksalnie - w kategoriach obrony (jugosłowiańskiej) wolności. Rezolucja Biura Informacyjnego zdaniem autora publikacji była

historycznym momentem zderzenia przemocy [reprezentowanej przez politykę Stalina - S.N.-B.] z wolnością, dzięki któremu polityka [Tity - S.N.-B.], posługując się z ło -

10 Od lat dziewięćdziesiątych zaczęło się ukazywać wiele publikacji na temat sposobów rozliczania się przez Titę z przeciwnikami politycznymi. Spośród prac poświęconych temu problemowi przywołuję jedynie książkę Naga Wyspa Božidara Jezernika, wydaną w Słowenii w 2013 roku z przedmową Adama Michnika. W tym samym roku ukazała się ona w Polsce (Jezernik). 
żonymi mechani z ma mi , wywalczyła sobie historyczne prawo do zajęcia autentycznej postawy rewolucyjnej i humanistycznej [wyróż. - S.N.-B.] (Marković 1986: 9).

Powyższy fragment nie tylko mówi o "złożonych mechanizmach”, które są eufemistycznym określeniem środków represji, ale także obnaża sposób prezentacji faktów oparty na mechanizmie mimikry polegającej - co pokazał Bhabha - na wytwarzaniu różnicy w tożsamości: kolonizowany (SFRJ) jest "prawie taki sam”, jak kolonizator (ZSRR), ale „nie całkiem” (Bhabha 185). Obozy pracy są elementem wspólnym titoizmu i stalinizmu. Opisując doświadczenia więźniów obozu stalinowskiego, Marković wykorzystuje książkę Sibirski pečat (Syberyjskie piętno) Vlady Oreškiego i Milana Nikolicia, wydaną w Zagrzebiu w 1983 roku, która opiera się na wspomnieniach Agaty Oreški z pobytu w żeńskim obozie Papinka. Sadystyczne okrucieństwo stosowanych tam metod zostaje przywołane jako przykład barbarzyństwa stalinowskiego terroru, co zakrawa na ironię w kontekście sposobu, w jaki Marković mówi o obozach Tity. Zdaniem krytyka w Jugosławii powstawały one w imię obrony wolności i prawa do samostanowienia jako standardowy "środek prewencyjny" przedsiębrany przeciwko zwolennikom Stalina, człowieka, który jugosłowiańską rewolucję postrzegał nie jako "samodzielny obiekt”, ale jako "przedmiot swojej polityki" (Marković 1986: 19). Marković przywołuje stanowisko Radovana Radonjicia, historyka biorącego aktywny udział także $w$ najnowszych dyskusjach o Nagiej Wyspie, oraz Vladimira Dedijera, historyka i zarazem oficjalnego biografa Tity (Dedijer 1953) ${ }^{11}$. Pierwszy z nich w książce Izgubljena orijentacija (Utracona orientacja) z 1985 roku sprzeciwiał się porównywaniu Nagiej Wyspy do hitlerowskich obozów koncentracyjnych czy gułagów Stalina, uzasadniając przemoc, której się w niej dopuszczano, wpływem czynników kształtujących psychikę człowieka "stąd”, a więc: „sposobem rozumienia przewinienia i metod jego eliminowania" oraz rygorystycznymi metodami wychowawczymi stosowanymi w jugosłowiańskiej armii i w szkolnictwie (Radonjić 1985: 80). Drugi z autorów twierdził natomiast, że nadużyć tych dopuściły się osoby przeszkolone w ZSRR. Znamienny jest fakt, że przywołując obszerny cytat ze wspomnieniowej publikacji Dedijera (Marković 1986: 15-16), Marković całkowicie pomija następujący, niezwykle istotny fragment jego wypowiedzi: „Wówczas nie wiedziałem, co tam się dzieje. Ale to wszystkich nas, którzy tak intensywnie zaangażowaliśmy się $w$ walkę przeciwko Stalinowi, [...]nie zwalnia od moralnej odpowiedzialności" [wyróż. - S.N.-B] (Dedijer 1969: 421).

Marković przywołuje prace historyków w ściśle określony sposób i w konkretnym celu. Przedstawia on bowiem większość utworów, powstałych w SFRJ

11 Znamienne są fotografie umieszczone na okładce biografii Tity, wydanej w USA jeszcze za jego życia, przedstawiające ich wspólne zdjęcie oraz kopię listu marszałka do autora - rodzaj „komentarza" (autoryzacji) publikacji. 
i podejmujących drażliwy temat, nie pomijając także dzieł, których twórcy bezkompromisowo i w jednoznacznie krytyczny sposób odnoszą się do problemu prześladowań politycznych, np. powieści Antonije Isakovicia Tren 2, przetłumaczonej na język polski w 1990 roku oraz książek prezentujących represje w kategoriach tragizmu ludzkiego życia wobec wyższej konieczności, z różnorodnie rozłożonymi akcentami (kładących większy nacisk na tragizm albo na historyczną konieczność) ${ }^{12}$. Nieselektywny sposób prezentacji umożliwia Markoviciowi pokazanie czytelniczej publiczności utworów niepoprawnych politycznie, w tym także tych, których autorzy podejmując problem Nagiej Wyspy i rozłamu w obrębie Partii Komunistów Jugosławii, nie wyrażają w utworach określonego stanowiska. Zarazem jednak autor książki Preispitivanja. Informbiro i Goli otok u jugoslovenskom romanu dezawuuje etyczny (krytyczny) wymiar tych utworów, bowiem jego zdaniem przyjęcie perspektywy ofiary bez ujawniania popełnionych przez nią błędów („winy”), jest, z punktu widzenia interesów rewolucji, „półprawdą” (Marković 1986: 11). Szczególnie zaskakujące są zarzuty Markovicia pod adresem powieści Tren 2: „Gdy [Isaković - S.N.-B.] mówi [w niej - S.N.-B.] o ogromie cierpienia więźniów Nagiej Wyspy, a nie wspomina nawet o rozmiarach zdrady, której się dopuścili" (Marković 1986: 183). Marković wysuwa je, pomijając (przeoczając?) pytanie, które pada w innym miejscu książki Isakovicia: „Kamienna Wyspa, i zola cja musiała być. Ale czy taka? [wyróż. - S.N.-B.]" (Isaković 150). Za jego sprawą powieść Tren 2 wpisuje się - paradoksalnie - w linię obrony Nagiej Wyspy poprzez problematyzację kwestii odpowiedzialności za zło, której - sądząc z negatywnej opinii wystawionej powieści nie tylko przez Markovicia ${ }^{13}$ - w latach osiemdziesiątych nie sposób było podjąć.

Znikoma liczba utworów poruszających tematykę Rezolucji Biura Informacyjnego i prześladowań przeciwników politycznych była - zdaniem chorwackiego krytyka - następstwem konieczności zdystansowania się pisarzy do problemu i zajęcia wobec niego "uzasadnionego historycznie" stanowiska, ale w istocie wynikała z ich „niegotowości” do zmierzenia się z tym tematem (Marković 1986: 52). Jeżeli jednak

12 W grupie tej znalazły się m.in. książki pisarzy serbskich: Dragoslava Mihailovicia Kad su cvetale tikve (Kiedy kwitna tykwy), przełożona na język polski (Mihailović), Magdy Simin Pomračenja (Zaćmienia) z 1972 roku, Pavle Ugrinova Zadat żivot (Zadane życie) z 1979 roku oraz Carstvo zemaljsko (Królestwo ziemskie) z 1982 roku, Vladimira Jovičicia Bio jednom jedan čovek (Był sobie kiedyś pewien człowiek) z 1982 roku, Slobodana Selenicia Pismo-glava (Orzeł-reszka) z 1982 roku, Dragana Lakićevicia Zemaljski ključ (Ziemski klucz) z 1985 roku, pisarzy czarnogórskich: Čedo Vukovicia Razvođe (Podział) z 1968 roku i Žarka Komanina Prestupna godina (Rok przestępny) z 1982 roku oraz pisarzy chorwackich: Dragana Kalajdžicia Otok gole istine (Wyspa nagiej prawdy) z 1985 roku i Mirka Kovača Vrata od utrobe (Drzwi żywota) z 1978 roku, przetłumaczona na język polski (Kovač) czy słoweńskich twórców: Vitomila Zupana Levitan z 1982 roku, Branka Hofmana Noč do jutra (Noc do jutra) z 1981 roku, przełożona na język polski (Hofman) i Ferdo Godiny, autora powieści Molčeći orkestar (Milcząca orkiestra) z 1981 roku.

13 W swoim artykule Otoci i kamenolomi opublikowanym po raz pierwszy w 1983 roku („Komunist”, 4.02. i 11.02.1983), Radovan Radonjić bardzo krytycznie odniósł się do utworów beletrystycznych podejmujących problem Nagiej Wyspy (Radonjić 1986: 147-155). 
"gotowość" mierzona jest przestrzenią wolności, którą oferuje system, to wydaje się, że retoryka Markovicia skrywała niemożność przekroczenia granicy autocenzury motywowanej strachem. O tym, że ów lęk nie był bezzasadny świadczy los publikacji, których autorzy zdecydowali się poruszyć tę tematykę $e^{14}$, opisany w innym miejscu książki (Marković 1986: 26-27) ${ }^{15}$. Syndrom „niegotowości” to eufemizm, wykorzystany przez niego w celu zróżnicowania tzw. prawdy jednostkowej i prawdy historycznej, w imię której jednostka musi zostać poświęcona na „ołtarzu ojczyzny". Przyjęcie perspektywy dobra nadrzędnego, którym jest wolność utożsamiana w wyborem jedynej słusznej drogi - drogi wyznaczonej przez Josipa Broza Titę - prowadzi do podważenia statusu ofiary, którą obciąża się odpowiedzialnością za przemoc, jakiej doznała.

Zastosowaną przez Markovicia narrację przewrotnie można określić mianem ocalającej. Z jednej strony retoryka politycznej poprawności umożliwia prezentację utworów niepokornych i sprawia, że utwory publikowane po Aferze Biura Informacyjnego w 1948 roku zostają wydobyte z przestrzeni zapomnienia i niebytu, ujawniając historyczną prawdę o czasach represji. Z drugiej jednak strony celem przedstawienia tych powieści jest udowodnienie, że prawda o Nagiej Wyspie nie była tabuizowana (czemu jednak wyraźnie przeczy wywód autora posługującego się strategią mimikry) i utrwalenie pozytywnego wizerunku SFRJ.

Przykład książki Markovicia, ujawniając subwersyjny potencjał mimikry, uświadamia problem, który w przededniu rozpadu Jugosławii poruszyła w swojej powieści Boba Blagojević ${ }^{16}$ - dramat ofiar jugosłowiańskiej drogi do komunizmu, których głos „zamiera” (Blagojević 1991: 268), ponieważ one same wyrażają zgodę na odebranie im głosu. Pomimo przemiany głównego bohatera powieści w „potwora" (jak sam siebie nazywa), niemożność przezwyciężenia własnej słabości nie uwalnia "szkarłatnego błazna” od świadomości niespłaconego „długu” wobec cierpiących, wyrażonego w słowach wieńczących jego spowiedź:

Widzę siebie $\mathrm{w}$ wagonie towarowym, pozbawionego powietrza, wody, związanego w ciężarówce, zamkniętego pod pokładem statku, który z trudem utrzymuje się na falach. Poniżony, głodny, czekam na kres tej podróży: anonimową wspólną śmierć, w masie nagich bądź przyodzianych ciał... ten sam ostatni krzyk... Jak wyrzucić z pamięci to, czego inni nie potrafią zapomnieć? Słyszę tych, których cierpienia upominają się o pamięć. Jaki to ciężar! [wyróż. - B.B.] (Blagojević 1991: 268).

14 Problemy Eriha Koša z publikacją książki U potrazi za Mesijom (W poszukiwaniu Mesjasza), która odczytana została jako opowieść o losach titoizmu, na podstawie dokumentów udostępnionych przez niego autorce opisuje Gordana Todorić (Todorić 304-305).

15 Problemy z wydaniem dotknęły powieści: Pismo-glava Slobodana Selenicia, Povratak predaka Čedo Vulevicia, Noč do jutra Branka Hofmana, Tren 2 Antonija Isakovicia i Arizani Ivana Ivanovicia.

$16 \mathrm{Z}$ fragmentów dziennika pisarki opublikowanych w drugim wydaniu powieści dowiadujemy się, że powieść powstawała pomiędzy 1980 a 1989 rokiem (Blagojević 2002: 380-385). 
Opowieść Boby Blagojević o dorastaniu w czasach titoizmu jest jedną z ciekawszych (także pod względem artystycznym), alternatywnych dla nurtu jugonostalgicznego, propozycji oceny spuścizny SFRJ.

\section{BIBLIOGRAFIA}

Ashcroft Bill, Griffiths Gareth, Tiffin Helen. Post-Colonial Studies. The Key Concepts. New York: Routledge, 2007.

Bachelard, Gaston. „Fenomenologia maski”. Przeł. Barbara Grzegorzewska. Maski. T. 2. Red. Janion Maria, Rosiek Stanisław. Gdańsk: Wydawnictwo Morskie, 1986. S. 14-24.

Bachtin, Michaił. „Formy czasu i czasoprzestrzeni w powieści”. Problemy literatury i estetyki. Przeł. Wincenty Grajewski. Warszawa: Czytelnik, 1982. S. 278-469.

Banac, Ivo. Sa Staljinom protiv Tita, informbirovski rascjepi u jugoslavenskom komunističkom pokretu. Zagreb: Globus, 1990.

Bekić, Darko. Jugoslavija u hladnom ratu. Zagreb: Globus, 1988.

Bela knjiga o agresivnim postupcima vlada SSSR-a, Poljske, Čehoslovačke, Mađarske, Rumunije, Bugarske i Albanije prema Jugoslaviji. Beograd: MIP FNRJ, 1951.

Bhabha, Homi. „Mimikra i ludzie. O dwuznaczności dyskursu kolonialnego”. Tłum. Tomasz Dobrogoszcz. Literatura na Świecie 1-2 (2008). S. 184-195. Bhabha, Homi. Of Mimicry and Man: the Ambivalence of Colonial Discourse's Civility. The location of culture. London: Routledge, 1994. S. 85-92. Pierwodruk: October 28 (1984 - Spring). S. 125-133.

Blagojević, Boba. Skerletna luda. Prva knjiga koja se zove i druga knjiga. Beograd - Sremski Karlovci: Miltas - Izdavačka knjižarnica Stojana Novakovića, 1991.

Blagojević, Boba. Skerletna luda. Prva knjiga koja se zove i druga knjiga, Novi Sad - Sremski Karlovci - Beograd: Izdavačka knjižarnica Stojana Novakovića - Altera, 2002.

Callois, Roger. Mimicry and Legendary Psychasthenia. Przeł. John Shepley. October 31 (1984 - Winter). S. 16-32. Web. 19.02.2017. <http://www.tc.umn.edu/ stou0046/caillois.pdf> Pierwodruk: Mimetisme et psychasthenie legendaire. Minotaure 7 (1935). S. 4-10.

Dedijer, Vladimir. Dokumenti o 1948. T. 1-3. Beograd: Izdavačka radna organizacija «Rad», 1980.

Dedijer, Vladimir. Izgubljena bitka Josifa Visarionoviča Staljina. Sarajevo: Svjetlost, 1969.

Dedijer, Vladimir. Novi prilozi za biografiju Broza Tita. T. 3. Beograd: Izdavačka radna organizacija «Rad», 1984.

Dedijer, Vladimir. Tito. New York: Simon and Schuster, 1953.

Domańska, Ewa. „Hermeneutyka przejścia (Wspomnienia z Rosji Jana Żarno)”. Historie niekonwencjonalne. Refleksja o przeszłości w nowej humanistyce. Poznań: Wydawnictwo Poznańskie, 2006. S. 131-159.

Domańska, Ewa. Obrazy PRL w perspektywie postkolonialnej. Studium przypadku. Web. 10.07.2016. <http:// www.staff.amu.edu.pl/ ewa/Domanska,\%20Obrazy\%20PRL\%20w\%20perspektywie\%20postkolonialnej.pdf>

Freud, Sigmund. „Nieświadomość”. Przeł. Marcin Poręba. Zofia Rosińska. Freud. Warszawa: Wiedza Powszechna, 2002. S. 193-225. 
Hirsch, Marianne. „Family Pictures: Maus, Mourning and Post-Memory”. Discours 2 (1992-93 - Winter). S. 3-29.

Hofman, Branko. Noc do jutra. Przeł. Joanna Pomorska. Warszawa: Czytelnik, 1988.

Isaković, Antonije. Ułamek sekundy 2. Przeł. Elżbieta Kwaśniewska. Warszawa: Czytelnik, 1990.

Jambrešić Kirin, Renata. „Izdajice su uvijek ženskog roda: političke zatvorenice u arhipelagu Goli”. UpEUnderground 17-18 (2010). S. 231-242.

Jambrešić Kirin, Renata. „Komunističko totalitarno nasilje: žene na Golom otoku i sv. Grguru”. Sjećanja žena žrtava nacizma i nedemokratskih režima. Ured. Sandra Prlenda. Zagreb: Centar za ženske studije, 2009. S. 47-67.

Jambrešić Kirin, Renata. „Verbalno nasilje i razgradnja kolektivnih identiteta u iskazima političkih zatvorenika i ratnih zarobljenika (1945-1995)". The Politics of Memorizing and Forgettimg: Reminiscences of the Second World War in Croatia. Bez miejsca i roku wydania. S. 39-57. Web. 10.08.2016. <http:/ / rss.archives.ceu.hu/archive/00001140/01/148.pdf>

Jezernik, Božidar. Naga Wyspa. Gułag Tity. Przeł. Joanna Pomorska i Joanna Sławińska, Wołowiec: Wydawnictwo Czarne, 2013.

Jung, Carl Gustav. „Picasso”. Archetypy i symbole. Pisma wybrane. Przeł. Jerzy Prokopiuk. Warszawa: Czytelnik, 1976. S. 489-496.

Kołakowski, Leszek. „Kapłan i błazen (Rozważania o teologicznym dziedzictwie współczesnego myślenia)". Pochwata niekonsekwencji. Pisma rozproszone z lat 1955-1968. T. 2. Przedmowa, wybór i opracowanie Zbigniew Mencel. Warszawa: Niezależna Oficyna Wydawnicza, 1989.

V. kongres Komunističke partije Jugoslavije: izvještaji i referati. Zagreb: Kultura, 1948.

VI. kongres KPJ/SKJ, Beograd: Kultura, 1952.

Kovač, Mirko. Drzwi żywota. Przeł. Grzegorz Łatuszyński. Łódź: Wydawnistwo Łódzkie, 1988.

Kranjec, Miško. Zgubljena vera. Ljubljana: Cankarjeva založba, 1954.

Kržavac Savo, Marković Dragan. Informbiro - šta je to? Jugoslavija je rekla ne. Beograd: Sloboda, 1976.

Kržavac Savo, Marković Dragan. Zavera informbiroa. Beograd - Ljubljana: Narodna knjiga - Partizanska knjiga, OOUR Izdavačko-publicistička delatnost, 1987.

Lacan, Jaques. „The Line and Light”. The Four Fundamental Concepts of Psychoanalysis. The Seminar of Jacques Lacan. Book XI. Transl. Alan Sheridan, New York - London: W.W. Norton\&Company, 1998. S. 91-104

Legutko, Ryszard. „Podzwonne dla błazna”. Bez gniewu i uprzedzenia. Szkice o ksiażkach, ludziach i ideach. Paryż: AKTIS, 1989.

Mandić, Igor. Književno (st)ratište. Kritika hrvatske tekstualnosti 1991-96/97. Zagreb: NZMH, 1998.

Marković, Dragan. Istina o Golom otoku. Beograd: Narodna knjiga - Partizanska knjiga, 1987.

Marković, Milivoje. Preispitivanja. Informbiro i Goli otok u jugoslovenskom romanu. Beograd: Narodna knjiga, 1986.

Mihailović, Dragoslav. Kiedy kwitna tykwy. Przeł. Dorota Jovanka Cirlić. Warszawa: PIW, 1979.

Petranović, Branko. Istorija Jugoslavije 1918.-1988. T. 3. Beograd: Nolit, 1988.

Pleterski Janko et al. Povijest Saveza komunista Jugoslavije. Beograd: Izdavački centar Komunist, Narodna knjiga, Rad, 1985.

Radonjić, Radovan. Izgubljena orijentacija. Beograd: Radnička štampa, 1985. 
Radonjić, Radovan. „O broju informbirovaca se ipak znalo”. Matica 58 (2014 - ljeto). S. 23-52.

Radonjić, Radovan, Otoci i kamenolomi. Politički eseji, Titograd: NIO Univerzitetska riječ, 1986.

Ribnikar, Jara. Nedovršeni krug. Beograd: Novo pokoljenje, 1954.

Starobinsky, Jean. „Portret artysty jako linoskoczka”. Przeł. Aleksandra Olędzka-Frybesowa. Literatura na Świecie 9 (1976). S. 308-323.

Svirčev, Žarka. Is-povest stranosti ili poetičke transgresije Bobe Blagojević. Web. 15.10.2016.

<http://www.academia.edu/16959720/Ispovest_stranosti_ili_poeti\%C4\%8Dke_transgresije_Bobe_ Blagojevi\%C4\%87>

Štrbac, Čedomir. Jugoslavija i odnosi između socijalističkih zemalja. Sukob KPJ i Informbiroa. Beograd: Institut za međunarodnu politiku i privredu, 1975.

Štrbac, Čedomir. Svedočanstva o 1948. Fragmenti za istoriju. Beograd: Zavod za udžbenike i nastavna sredstva, 1989.

Sznajderman, Monika. „«Tam, gdzie Bóg nie ukończył swego dzieła». Szkic o królu, błaźnie i nowej demiurgii". Polska Sztuka Ludowa 51, 1-2 (1997). S. 124-131.

Taczyńska, Katarzyna. „Diskurs o logoru Goli otok - ženska perspektiva”. Knjiženstvo 4 (2014). Web. 23.09.2016. <http://www.knjizenstvo.rs/magazine.php?text=130>

Todorić, Gordana. „Verski pokret Sabataja Cvija i jedna književna afera, tri stotine godina kasnije”. Religija i tolerancija 24 (2015). S. 301-308.

Wańkowicz, Melchior. Karafka La Fontaine'a. T. 2. Kraków: Wydawnictwo Literackie, 1984. 